\title{
First Detection of Human Polyomaviruses in HIV Patients with Suspected Neurological Disease in Montería, Colombia
}

\author{
Vaneza Tique1, Samia Barrera', Salim Mattar ${ }^{1,2 *}$, Jorge Miranda1 ${ }^{1}$, Francisco Camargo ${ }^{3}$ \\ ${ }^{1}$ University of Cordoba, Instituto de Investigaciones Biologicas del Tropico, Córdoba, Colombia \\ ${ }^{2}$ Clinica Salud Social, Sincelejo, Sucre \\ ${ }^{3}$ Clinica Zayma, Intensive Care Unit, Monteria, Cordoba \\ Email: *mattarsalim@hotmail.com, smattar@correo.unicordoba.edu.co
}

Received 18 November 2015; accepted 21 February 2016; published 24 February 2016

Copyright (C) 2015 by authors and Scientific Research Publishing Inc.

This work is licensed under the Creative Commons Attribution International License (CC BY). http://creativecommons.org/licenses/by/4.0/

\section{(c) (i) Open Access}

\begin{abstract}
Objective: The objective is to establish the presence of JC and/or BK polyomavirus in HIV patients with symptoms of encephalitis and/or meningitis. Methodology: From September 2009 to December 2011, a prospective study was conducted. 34 HIV patients with symptoms consistent with encephalitis and/or meningitis were included. The work was conducted in 3 hospitals in the city of Monteria. Viral DNA extraction was performed on samples of cerebrospinal fluid (CSF) using a commercial kit (Quiagen, USA). The detection of BKV and JCV was performed by multiplex realtime PCR (LightMix ${ }^{\circledR}$, Roche Diagnostics, Germany) with primers specific for the short $t$ antigen gene fragment, labeled probes and one internal control. Results: In 9 (26\%) of 34 patients included in the study, JCV virus was detected; only $1(3 \%)$ patient had coinfection with JCV/BKV. The mortality rate was $3 \%$. The cytochemical examination of CSF in positive patients presented average values: $40.7 \mathrm{mg} / \mathrm{dL}$ glucose, $171.66 \mathrm{mg} / \mathrm{dL}$ protein, $19.8 \mathrm{~mm}^{3}$ leukocytes, and $109.8 \mathrm{~mm}^{3}$ erythrocytes. Conclusion: The findings demonstrate that JCV and BKV have a significant occurrence in HIV patients with CSF infections in Monteria.
\end{abstract}

\section{Keywords}

Progressive Multifocal Leukoencephalopathy, Meningitis, Encephalopathy, AIDS

\section{Introduction}

Human polyomaviruses belong to the family Papovaviridae. BK virus (BKV) and JCV virus are the principal

"Corresponding author.

How to cite this paper: Tique, V., Barrera, S., Mattar, S., Miranda, J. and Camargo, F. (2015) First Detection of Human Polyomaviruses in HIV Patients with Suspected Neurological Disease in Montería, Colombia. Modern Research in Inflammation, 4, 25-31. http://dx.doi.org/10.4236/mri.2015.43003 
members of this group that affect human beings [1] [2]

Nearly $70 \%$ to $80 \%$ of healthy people have antibodies against BKV and JCV [3] [4]. Initial infection with both BKV and JCV occurs commonly in childhood or in adolescence and is generally asymptomatic [5]. These viruses can persist latently in many sites, including kidneys, CNS and lymphoid cells. Recrudesce of latent infection may then occur in immunocompromised individuals [6].

The occurrence of BKV and JCV in people infected with human immunodeficiency virus (HIV) ranges from $20 \%$ - 44\% [7]. In immunecompromised patients, JCV is the main etiologic agent of progressive multifocal leukoencephalopathy (PML), a fatal neurological disease, as well as granular cell neuropathy, encephalopathy and meningitis, the BKV is associated with hemorrhagic cystitis in stem cell transplantation (HSCT) hematopoietic and interstitial nephropathy in kidney transplant recipients, it has recently been shown that is associated with neurological complications [4] [8] [9].

Nonetheless, PML prevalence frequently increases during AIDS epidemics, where up to $5 \%$ of AIDS patients may develop the disease. In fact, the mortality associated with PML has also expanded from 1.5 per ten million people in the initial HIV era to 6.1 deaths per ten million persons in the post HIV era [9].

Currently, a new PML presentation has appeared among patients managed with immunomodulatory drugs for autoimmune diseases [9]-[11]. BKV is associated with hemorrhagic cystitis in hematopoietic stem cell transplantation recipients and interstitial nephropathy in kidney transplant recipients and has lately also been demonstrated to be related to neurologic exacerbations [4].

There are about 1.7 million people infected with HIV in Latin America and 250,000 in the Caribbean in Colombia in 2014, In Cordoba, 9700 cases were reported, with a mortality rate of $6.7 \%$ and 380 of these cases were notified as HIV/AIDS positive [12]-[14].

Between 1992-2000 in Brazil and Mexico, the prevalence of PML in postmortem samples of patients confirmed with AIDS was between $0.8 \%$ and $3 \%$ [15]. In Colombia, only four cases of polyomavirus infection have been reported, Triana et al., [16] reported the first case of PML in Latin America and Colombia (Bogotá) associated with natalizumab in a patient with a diagnosis of multiple sclerosis; the virus was identified in brain biopsy using the technique of in situ hybridization. In Cali, Cadavid et al. [17] studied two patients with kidney transplants; BKV was identified by immunohistochemistry in a kidney biopsy. However, there are no studies in Colombia on polyomavirus in HIV individuals associated with neurologic disease.

The objective of this study was to detect JCV and BKV in HIV patients with symptoms consistent with encephalitis and/or meningitis.

\section{Materials and Methods}

\subsection{Patients and Specimens}

34 CSF specimens were collected from HIV patients with suspected meningitis and/or encephalitis between September 2009 and December 2011, at the San Jerónimo of Monteria hospital main clinical center of third level of care of the department of Cordoba. 25 patients were males and 9 females aged 3 - 63 years. CSFs were frozen at $-80^{\circ} \mathrm{C}$ until processing. The selection of patients was independent of group age, gender and membership in health system, the selection criteria were: patients with diagnosis of suspected encephalitis [18] was defined as: fever, headache, convulsions, signs of brain involvement, such as alteration of consciousness and/or personality, seizures and focal neurologic signs and the diagnosis of suspected meningitis [19] was defined as: fever, headache, neck stiffness.

\subsection{Molecular Detection of JC and BK Viruses}

Polyomavirus DNA was extracted from $200 \mu \mathrm{l}$ of CSF samples using a resin column kit (Quiagen, USA Cat. 51306) according to the manufacturer's instructions. The DNA was kept at $-20^{\circ} \mathrm{C}$ until processing. To detect JCV and BKV a kit LightMix ${ }^{\circledR}$ polyomaviruses JC and BK (Cat-40-0203-32, Roche Diagnostics, Tibmolbiol), multiplex PCR in real-time was performed. The kit amplifies a fragment of the gene encoding $t$ antigen $175 \mathrm{bp}$ (BKV) and 172 bp (JCV). In each test negative and positive controls and internal standards were included; those were used to generate viral load curves for JCV and BKV $\left(10^{1}\right.$ to $\left.10^{6}\right)$.

\subsection{Laboratory Data}

The CSFs were analyzed by: tests of glucose and protein levels, cell count of leukocytes and erythrocytes, Chi- 
nese ink, Gram staining, Ziehl-Neelsen and culture.

\subsection{Ethics}

Institutional standard guidelines of the Minister of Health of Colombia and University of Cordoba ethics committee were followed for the collection of patient's CSF samples after obtaining their written informed consent for involvement in the study. All ethics issues were according to the resolution number 8430 of 1993 [20]. During the study confidentiality of the information was maintained.

\subsection{Statistics}

Chi-square test and ANOVA were used for statistical analysis. Analysis was performed in EpiInfo Version 7.1 (CDC, Atlanta) software. $\mathrm{P}<0.05$ was considered significant.

\section{Results}

Between September 2009 and December 2011, 34 HIV patients with neurological manifestations were studied. The median age of the cohort was 33.5 years (range, 3 - 63 years); of these 34 patients 25 (74\%) were male and 9 (26\%) were female.

\subsection{Clinical Features}

The following clinical manifestations were found in 34 patients: 28 (82\%) patients presented with headache, 20 (59\%) fever, 14 (41\%) nausea, 12 (35\%) neck rigidity, 11 (33\%) convulsions, 8 (24\%) altered mental status, 7 (21\%) decrease of the muscular force, 4 (12\%) irritability, 3 (9\%) disartria, 2 (6\%) hipoestesia and 1 (3\%). flaccid paralysis. CSF samples showed opportunistic pathogens in 6 of 34 (18\%) patients; 4 (12\%) patients had Cryptococcus neoformans and 2 (6\%) were infected by Treponema pallidum. The hematological and biochemical parameters were as follows: leukocyte count (average $54.03 / \mathrm{mm}^{3}$ ), predominantly mononuclear (average $15 \%$ ), erythrocyte count (average $44.96 \mathrm{~mm}^{3}$ ), glucose levels (average $35.12 \mathrm{mg} / \mathrm{dl}$ ), and increase in protein (average $130.11 \mathrm{mg} / \mathrm{dl}$ ).

\subsection{Detection of JCV and BKV in CSF}

JCV was detected in 9/34 patients (26\%), with a mean viral load of 1.535 copies/ $\mu$ l (range, $500-1,000,000$ copies/ $\mu \mathrm{l})$. One patient (3\%) had coinfection with JCV/BKV; a viral load of 850 copies/ $\mu$ l of JCV and 650 copies/ $\mu \mathrm{l}$ of BKV were found. Viral load, PCR and hematological and biochemical parameters are described in Table 1 . There were no significant differences in the age, sex, clinical manifestations and patients with infection by JCV and BKV.

\subsection{Clinical Presentation of Patients with Infection by JCV and BKV}

The median age was 35 years (range, 3 - 62 years). Only one of 34 (3\%) patients died with infection by JCV (Table 1). Patients with JCV or BKV infection presented the following signs and symptoms: headache (80\%), fever (70\%), seizures (40\%), vomiting (40\%) and nausea, decreased muscle strength, nuchal rigidity and hypoesthesia, altered mental status were seen with less frequency (Table 1). Ten patients showed glucose average of $40.7 \mathrm{mg} / \mathrm{dl}$, protein levels had an average of $171.66 \mathrm{mg} / \mathrm{dl}$, protein levels were elevated in only 3 patients. Regarding hematological patterns, the leukocytes had an average of $19.8 \mathrm{~mm}^{3}$, erythrocytes had an average of $109.8 \mathrm{~mm}^{3}$, predominantly mononuclear $10 \%$, in 3 patients the leukocyte count was elevated (Table 1 ).

\section{Discussion}

This is the first prospective study carried out in Colombia in HIV patients infected by JCV and BKV; all HIV patients enrolled in the study had suspected meningitis or encephalitis. The overall prevalence was $26 \%$ for polyomavirus and 3\% of coinfection with JCV/BKV. The frequency of infection with JCV was significantly higher than other studies, which reported infection rates of $6 \%$ with JCV and coinfections with JCV/BKV in only 3.3\% (Table 1). In several studies carried out in urine samples, cervical carcinoma, semen and saliva, the detection 


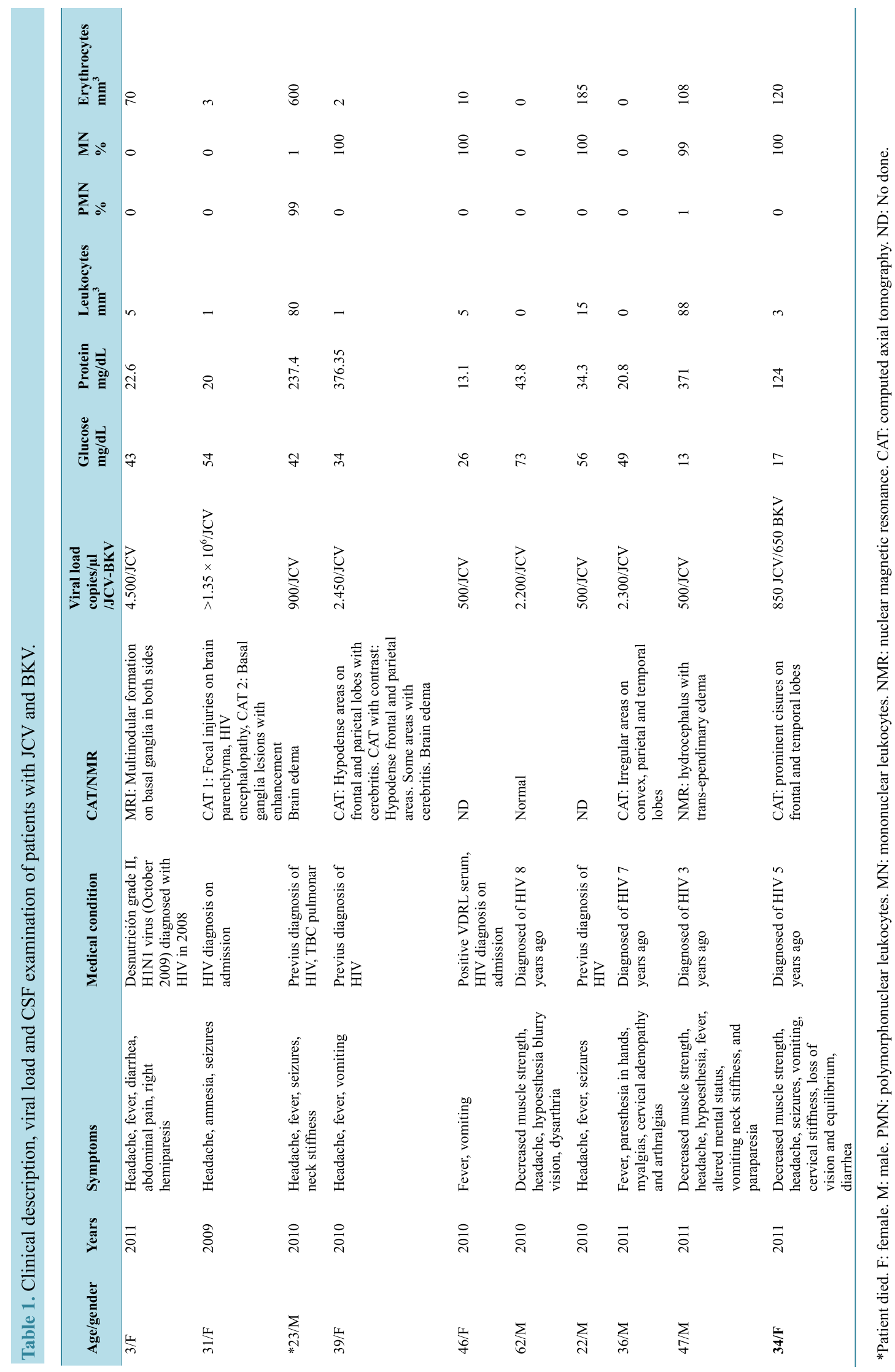


rate of JCV was $44 \%$ and $19 \%$ for BKV; coinfections were detected in up to $56 \%$ mainly in HIV patients. These data demonstrate the importance of epidemiological surveillance and the role of these viruses in neurological, renal and respiratory diseases and in cancer (Table 2).

The human polyomaviruses have been associated with individuals infected with HIV in whom the prevalence is higher than in healthy people [21]. This could explain the frequency of detection in the present study and its association with HIV and diseases of the CNS. However, most of the studies, including our work, analyzed samples of hospitalized patients, which may explain the high prevalence rates compared with low rates in healthy patients [22].

In African HIV patients, a rate of $6 \%$ of JCV was detected in CSF and it was not associated with PML diagnosis. PML was not evaluated in the present study because nuclear magnetic resonance (NMR) and computed axial tomography (CAT) imagines were not available; we obtained only radiological image interpretations. Nevertheless, in our patients infected by JCV/BKV, there were strong clinical presentations compatible with meningitis or encephalitis [6].

The detection of JCV in patients with meningitis or encephalitis and its causal association with these illnesses has been documented and it has been established that 2 of each 131 patients with initial diagnosis of meningitis or encephalitis are infected by JCV and they present with typical symptoms such as migraine, dizziness, nuccal rigidity and diplopia. In contrast, PML differs from polyomavirus infection, in that PML has neurological deficits, absence focal and focal injuries in the white matter of the brain. In the present study, the clinical manifestations are similar to those described in the literature for the neurological complications associated with these viruses [9].

The neurological problems arising from infection with BKV have been described extensively; meningo-encephalitis is common in immunecompromised patients [1]. In the present study, a JCV/BKV coinfection was identified in a patient with a clinical picture compatible with infection of the CNS; however, the patient did not present significant neurological complications.

With regard to the laboratory findings, the CSF of patients with infection by JCV did not show remarkable changes, although there was an increase in cell count, protein and increased glucose levels. In the present study, we observed a 33\% shift in the CSF, similar to that reported by Netravathi et al. (2013) [23] and Berger 2014 [24].

Table 2. Studies on JCV and BKV in different countries.

\begin{tabular}{|c|c|c|c|c|c|}
\hline Country & Sample & Method & Nro. of patients & Prevalence & Reference \\
\hline Brasil & Urine & PCR & $\begin{array}{l}160 \text { children HIV+ } \\
\text { y } 60 \text { healthy } \\
\text { children }\end{array}$ & $\begin{array}{c}25 \% \mathrm{JCV} ; 40 \% \\
\text { BKV }\end{array}$ & [7] \\
\hline Brasil & Saliva & PCR-TR & $\begin{array}{l}60 \text { children HIV+y } \\
60 \text { healthy children }\end{array}$ & 3\% JCV; 6\% BKV & [27] \\
\hline Brasil & Urine & PCR & 75 HIV+ & $\begin{array}{c}\text { 19\% BKV; } 14.7 \% \\
\text { JCV; } 56 \% \\
\text { coinfection }\end{array}$ & [4] \\
\hline Italy & Urine y semen & PCR-TR & $\begin{array}{l}212 \text { infertile men y } \\
200 \text { fertile men }\end{array}$ & $\begin{array}{c}\text { 34\% JCV, } 1 \% \text { BKV } \\
\text { in infertile; } \\
20 \% \text { JCV, } 1 \% \\
\text { BKV fertile }\end{array}$ & [28] \\
\hline Serbia & Urine & PCR & $\begin{array}{l}93 \text { HIV+/107 } \\
\text { healthy }\end{array}$ & $\begin{array}{l}\text { 44\% JCV HIV+; } \\
32 \% \text { JCV healthy }\end{array}$ & [22] \\
\hline Kenia & $\begin{array}{l}\text { Cervical smears } \\
\text { Cervical } \\
\text { carcinomas }\end{array}$ & PCR & $\begin{array}{c}\text { healthy } \\
\text { women/HIV+ }\end{array}$ & $\begin{array}{c}5 \% \text { and } 16 \% \text { JCV } \\
\text { HIV+, } 8 \% \text { and } 6 \% \\
\text { JCV healthy }\end{array}$ & [29] \\
\hline África & CSF & PCR/ELISA & $\begin{array}{c}131 \text { meningitis } \\
\text { and/or encephalitis }\end{array}$ & $\begin{array}{c}4 \% \text { BKV; } 2 \% \text { JCV } \\
3 \% \text { coinfection }\end{array}$ & {$[6]$} \\
\hline Zambia & CSF & PCR & 331 adult HIV+ & $6 \% \mathrm{JCV}$ & [30] \\
\hline India & CSF & PCR/MRI & 1.965 HIV+ & 3\% JCV & [23] \\
\hline Colombia & CSF & PCR-TR & $34 \mathrm{HIV}+$ & $\begin{array}{c}\text { 26\% JCV; 3\% } \\
\text { BKV/JCV }\end{array}$ & Present study \\
\hline
\end{tabular}


In the present study for the first time in Colombia, we used a multiplex PCR for the detection in CSF samples of JCV and BKV in a HIV population with clinical suspicion of neurological disease. Molecular techniques are useful and reliable tools for the diagnosis of viral agents of clinical importance. In the case of JCV/BKV, the sensitivity of the PCR in CSF was 72\% - 92\% and the specificity 92\% - 100\%; our results thus confirm that PCR is a useful test for diagnosing polyomavirus infection [1] [25]. However, the present work has limitations in the radiological images, because several patients are often difficult to distinguish between PML and encephalopathy by HIV [26]. On the other hand, the small number of samples (34 patients), it does not allow a conclusive statistical analysis, because there were no significant differences between the groups.

\section{Conclusion}

In conclusion, in the present study, polyomavirus were detected for the first time in Colombia in HIV patients. The significant polyomavirus frequency suggests a possible association of these viruses with infections of the CNS.

\section{Acknowledgements}

We thank Colciencias \& University of Cordoba-CIUC, who supported program for young researchers contract \#617-2014. We also thank to Dr. Ben Adler for the critics of the manuscript, and Misael Oviedo, PhD, for the statistics analysis.

\section{References}

[1] Pinto, M. and Dobson, S. (2014) BK and JC Virus: A Review. Journal of Infectio, 68, S2-S8.

[2] Dekeyser, M., Francois, H., Beaudreuil, S. and Durrbach, A. (2015) Polyomavirus-Specific Cellular Immunity: From BK-Virus-Specific Cellular Immunity to BK-Virus-Associated Nephropathy? Frontiers in Immunology, 6, 307. http://dx.doi.org/10.3389/fimmu.2015.00307

[3] Jiang, M., Abend, J.R., Johnson, S.F. and Imperiale, M.J. (2009) The Role of Polyomaviruses in Human Disease. Virology, 384, 266-273. http://dx.doi.org/10.1016/j.virol.2008.09.027

[4] Nali, L.H., Centrone Cde, C., Urbano, P.R., et al. (2012) High Prevalence of the Simultaneous Excretion of Polyomaviruses JC and BK in the Urine of HIV-Infected Patients without Neurological Symptoms in Sao Paulo, Brazil. Revista do Instituto de Medicina Tropical de São Paulo, 54, 201-205. http://dx.doi.org/10.1590/S0036-46652012000400004

[5] De Gascun, C.F. and Carr, M.J. (2013) Human Polyomavirus Reactivation: Disease Pathogenesis and Treatment Approaches. Clinical \& Developmental Immunology, 2013, Article ID: 373579. http://dx.doi.org/10.1155/2013/373579

[6] Behzad-Behbahani, A., Klapper, P.E., Vallely, P.J., Cleator, G.M. and Bonington, A. (2003) BKV-DNA and JCVDNA in CSF of Patients with Suspected Meningitis or Encephalitis. Infection, 31, 374-378.

[7] Machado, D.M., Fink, M.C., Pannuti, C.S., et al. (2011) Human Polyomaviruses JC and BK in the Urine of Brazilian Children and Adolescents Vertically Infected by HIV. Memórias do Instituto Oswaldo Cruz, 106, 931-935. http://dx.doi.org/10.1590/S0074-02762011000800006

[8] Verbeeck, J., Van Assche, G., Ryding, J., et al. (2008) JC Viral Loads in Patients with Crohn's Disease Treated with Immunosuppression: Can We Screen for Elevated Risk of Progressive Multifocal Leukoencephalopathy? Gut, 57, 1393-1397. http://dx.doi.org/10.1136/gut.2007.145698

[9] Tan, C.S. and Koralnik, I.J. (2010) Progressive Multifocal Leukoencephalopathy and Other Disorders Caused by JC Virus: Clinical Features and Pathogenesis. The Lancet Neurology, 9, 425-437. http://dx.doi.org/10.1016/S1474-4422(10)70040-5

[10] Boothpur, R. and Brennan, D.C. (2010) Human Polyomaviruses and Disease with Emphasis on Clinical BK and JC. Journal of Clinical Virology, 47, 306-312. http://dx.doi.org/10.1016/j.jcv.2009.12.006

[11] Iannetta, M., Bellizzi, A., Lo Menzo, S., et al. (2013) HIV-Associated Progressive Multifocal Leukoencephalopathy: Longitudinal Study of JC Virus Non-Coding Control Region Rearrangements and Host Immunity. Journal of NeuroVirology, 19, 274-279. http://dx.doi.org/10.1007/s13365-013-0167-9

[12] Instituto Nacional de Salud. Informe del comportamiento en la notificación de vih-sida hasta el periodo epidemiológico 13 del año 2014. Informe de Evento, FOR-R02.4000-001(2), 1-22.

http://www.ins.gov.co/lineas-de-accion/Subdireccion-Vigilancia/Informe\%20de\%20Evento\%20Epidemiolgico/VIH\%2 0SIDA\%20\%202014.pdf

[13] Instituto Nacional de Salud, Dirección de Vigilancia y Analisis Del Riesgo en Salud Pública, Sistema de Vigilancia en 
Salud Pública (SIVIGILA). Boletin epidemiologico semanal, Semana epidemiológica número 53 de 2014 (28 dic. al 03 ene 2015).

http://www.ins.gov.co/boletin-epidemiologico/Boletn\%20Epidemiolgico/2014\%20Boletin\%20epidemiologico\%20sem ana\%2053.pdf

[14] Instituto Nacional de Salud, Dirección de Vigilancia y Analisis Del Riesgo en Salud Pública, Sistema de Vigilancia en Salud Pública (SIVIGILA). Estadísticas. Vigilancia rutinaria. Casos confirmados VIH/SIDA por departamento año 2014. http://www.ins.gov.co/lineas-de-accion/Subdireccion-Vigilancia/sivigila/Paginas/vigilancia-rutinaria.aspX

[15] Khalili, K. and Stoner, G.L. (2004) Human Polyomaviruses: Molecular and Clinical Perspectives. John Wiley \& Sons, New York.

[16] Triana, J., Reyes, M., Hernández, L., Mendoza, O., Salgado, S. and Becerra, G.P. (2014) Leucoencefalopatía multifocal progresiva asociada al uso de natalizumab en un paciente con esclerosis múltiple. Primer caso en Latinoamérica. Hospital de San José-Bogotá 2013. Acta Neurológica Colombiana, 30, 200-204.

[17] Cadavid, D., Mesa, L., Schweineberg, J. and Posada, J.G. (2015) Polyomavirus-Associated Nephropathy in Renal and Simultaneous Pancreas-Kidney Transplant Recipients: Report of Three Cases. Saudi Journal of Kidney Diseases and Transplantation, 26, 94-97. http://dx.doi.org/10.4103/1319-2442.148750

[18] Venkatesan, A., Tunkel, A.R., Bloch, K.C., et al. (2013) Case Definitions, Diagnostic Algorithms, and Priorities in Encephalitis: Consensus Statement of the International Encephalitis Consortium. Clinical Infectious Diseases, 57, 1114-1128. http://dx.doi.org/10.1093/cid/cit458

[19] Swanson II, P.A. and McGavern, D.B. (2015) Viral Diseases of the Central Nervous System. Current Opinion in Virology, 11, 44-54. http://dx.doi.org/10.1016/j.coviro.2014.12.009

[20] Republica de Colombia, Ministerio de Salud. Resolución No. 008430 del 4 de octubre del 1993. Por la cual se establecen las normas científicas, técnicas y administrativas para la investigación en salud, 1993.

[21] Wiedinger, K., Bitsaktsis, C. and Chang, S. (2014) Reactivation of Human Polyomaviruses in Immunocompromised States. Journal of NeuroVirology, 20, 1-8. http://dx.doi.org/10.1007/s13365-014-0234-X

[22] Karalic, D., Lazarevic, I., Knezevic, A., Cupic, M., Jevtovic, D. and Jovanovic, T. (2014) Distribution of JC Virus Genotypes among Serbian Patients Infected with HIV and in Healthy Donors. Journal of Medical Virology, 86, 411418. http://dx.doi.org/10.1002/jmv.23796

[23] Netravathi, M., Mahadevan, A., Satishchandra, P., et al. (2013) Progressive Multifocal Leukoencephalopathy (PML) Associated with HIV Clade C-Is Not Uncommon. Journal of NeuroVirology, 19, 198-208. http://dx.doi.org/10.1007/s13365-013-0168-8

[24] Berger, J.R. (2014) Progressive Multifocal Leukoencephalopathy. Handbook of Clinical Neurology, 123, 357-376. http://dx.doi.org/10.1016/B978-0-444-53488-0.00017-1

[25] Palazzo, E. and Yahia, S.A. (2012) Progressive Multifocal Leukoencephalopathy in Autoimmune Diseases. Joint Bone Spine, 79, 351-355. http://dx.doi.org/10.1016/j.jbspin.2011.11.002

[26] Wang, Y., Kirby, J.E. and Qian, Q. (2009) Effective Use of JC Virus PCR for Diagnosis of Progressive Multifocal Leukoencephalopathy. Journal of Medical Microbiology, 58, 253-255. http://dx.doi.org/10.1099/jmm.0.004432-0

[27] Robaina, T.F., Mendes, G.S., Benati, F.J., et al. (2013) Polyomavirus in Saliva of HIV-Infected Children, Brazil. Emerging Infectious Diseases, 19, 155-157. http://dx.doi.org/10.3201/eid1901.120563

[28] Comar, M., Zanotta, N., Croci, E., et al. (2012) Association between the JC Polyomavirus Infection and Male Infertility. PLOS ONE, 7, e42880. http://dx.doi.org/10.1371/journal.pone.0042880

[29] Behzad-Behbahani, A., Klapper, P.E., Vallely, P.J., Cleator, G.M. and Bonington, A. (2003) BKV-DNA and JCVDNA in CSF of Patients with Suspected Meningitis or Encephalitis. Infection, 31, 374-378.

[30] Siddiqi, O.K., Ghebremichael, M., Dang, X., et al. (2014) Molecular Diagnosis of Central Nervous System Opportunistic Infections in HIV-Infected Zambian Adults. Clinical Infectious Diseases, 58, 1771-1777. http://dx.doi.org/10.1093/cid/ciu191 